Brit. F. vener. Dis. (1974) 50, 251

\title{
Modified method of filtering cerebrospinal fluid and aqueous humour for the detection of treponemes Proof of the persistence of their vitality in rabbits
}

\author{
P. COLlaRT, P. FRANCESCHINI, M. POITEVIN, F. DUNOYER, AND M. DUNOYER \\ Institut Alfred Fournier, Paris
}

Since its discovery by Schaudinn and Hoffmann (1905), many authors have looked for Treponema pallidum in the cerebrospinal fluid with varying degrees of success. Sézary and Paillard (1910) first succeeded in detecting spirochaetes in the CSF and Nichols and Hough (1913) were able to isolate the strain which bears their name.

Shortly afterwards, Wile (1917) succeeded, 62 times out of 100 , in infecting rabbits with the CSF of a patient suffering from tabes and GPI, and Chesney and Kemp (1924), having similarly inoculated the CSF collected from 34 subjects with primary syphilis and one with syphilitic meningitis, all untreated, obtained six positive responses, although after a long incubation period.

Nedden (1906) had reported finding the organism in the aqueous humour of a patient with syphilitic iritis and Stephenson (1907) in that of a young woman with secondary syphilis and iritis.

The demonstration of $T$. pallidum in either the CSF or the aqueous humour requires very lengthy examination, because, except in cases of local lesions, the treponemes are present there in only very small numbers.

The technique advocated by Chandler and Clark (1970), which consists in filtering the CSF through a Millipore membrane filter and then applying the fluorescent conjugate directly to the filter, does not allow prolonged examination because of the rapid fading of the brightness of the material through the operation of the ultraviolet radiation.

To overcome this disadvantage we decided to replace the fluorescent technique by a silver-staining method that would allow examination over a long period.

Received for publication December 12, 1973

Address: Experimental Syphilis Laboratory, 25 Boulevard Saint Jacques, 75014 Paris, France

\section{Material and methods}

The procedure is extremely simple and differs but little from that proposed by Chandler and Clark (1970).

(1) APPARATUS

(a) A sterile $5 \mathrm{ml}$. syringe with a well-fitting plunger and a bayonet-type fixation.

(b) A filter-holder of the type that fits on to a sterile hypodermic syringe.

(c) A Millipore filter of $0.22 \mu$ pore size which, according to Chandler (1969), will not let any $T$. pallidum pass through.

(d) A pair of sterile tweezers.

(e) Several absolutely clean slides, previously rinsed with alcohol.

\section{(2) METHOD}

The filter having been placed in the holder, the adapter is screwed hermetically tight and fixed to the end of the syringe, which is then filled with the liquid to be examined. Should the viscosity of the medium be too high (as in the case of aqueous humour), the specimen can be diluted with a little sterile saline solution, which facilitates passage through the filter. Gentle pressure on the plunger should allow the liquid to flow out easily.

When this operation is completed, the adapter is unscrewed, and the filter is removed with sterile tweezers and placed on a sterile slide, with the side that was in contact with the specimen downwards. Smears are then made over the entire surface of one or two slides, and, after being allowed to dry, these are stained by Dunoyer's silver method (Collart, Borel, and Durel, 1962). The treponemes stain dark brown and stand out clearly against the light background.

This technique offers two advantages:

(a) A thinner smear with a relatively high concentration of $T$. pallidum;

(b) The fact that the slides can be kept enables them to be examined for a longer period of time. 


\section{Results}

(1) EXamination of CSF (Table I)

We examined by this method $49 \mathrm{CSF}$ specimens from infected rabbits obtained from $5 \mathrm{hrs}$ up to 1,420 days (i.e. nearly 4 yrs) after intratesticular inoculation with $1.5 \times 10^{6}$ treponemes.

Using the silver-staining method, we were able to find $T$. pallidum in all these smears except two, after examining them for different lengths of time (Fig. 1).

To make sure that the spirochaetes were in fact $T$. pallidum, we injected these fluids on several occasions into the testes of fresh rabbits. Once, using

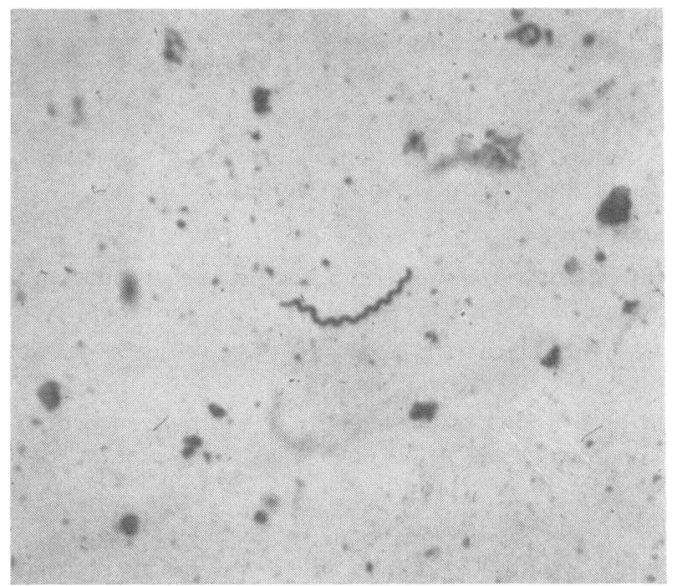

FIG. 1 Smear of CSF from a rabbit inoculated 12 days earlier material from a rabbit infected with syphilis 90 days previously, we obtained a typical orchitic reaction (confirmed bacteriologically) in the recipient, after an incubation period of 34 days.

Since, however, the quantity of CSF extracted by suboccipital puncture is extremely small (approximately $0.5 \mathrm{ml}$.), we constituted 'pools' of fluid on four occasions. Each of these pools contained the mixed CSF from four rabbits that had been infected for similar periods : $24 \mathrm{hrs,} 9$ days, 12 days, and 65 days respectively.

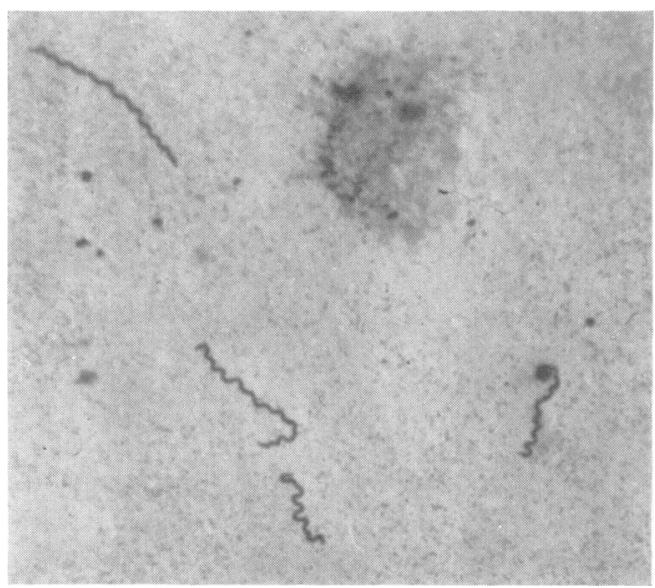

FIG. 2 Smear of material from acute orchitis after intratesticular inoculation of a 'pool' containing mixed CSF from four infected rabbits

TABLE I Results of bacteriological tests on CSF of infected (and untreated) rabbits and of intratesticular inoculations into fresh rabbits

\begin{tabular}{|c|c|c|c|c|}
\hline No. of rabbits & $\begin{array}{l}\text { Duration of infection before } \\
\text { collection of material }\end{array}$ & $\begin{array}{l}\text { Results of bacteriological } \\
\text { tests }\end{array}$ & $\begin{array}{l}\text { Results of injection of CSF } \\
\text { into testes of fresh rabbits }\end{array}$ & $\begin{array}{l}\text { Duration of } \\
\text { incubation } \\
\text { period (days) }\end{array}$ \\
\hline 7 & $\begin{array}{l}5,15,18,18,18,48 \text { and } \\
48 \text { hrs }\end{array}$ & Tp 7 positive & & \\
\hline 6 & $3,4,5,5,6$, and 9 days & $\begin{array}{r}\text { Tp } 5 \text { positive } \\
1 \text { negative }\end{array}$ & & \\
\hline 9 & $\begin{array}{l}10,10,10,10,12,12,12, \\
12, \text { and } 15 \text { days }\end{array}$ & $\begin{array}{r}\text { Tp } 8 \text { positive } \\
1 \text { negative }\end{array}$ & & \\
\hline 6 & $\begin{array}{l}90,98,118,118,186, \text { and } \\
199 \text { days }\end{array}$ & Tp 6 positive & $\begin{array}{l}1 \text { positive passage ( } 90 \text { days) } \\
2 \text { negative passages }\end{array}$ & 34 \\
\hline 5 & $\begin{array}{l}391,1,237,1,262,1,420 \text {, and } \\
1,420 \text { days }\end{array}$ & Tp 5 positive & 4 negative passages & \\
\hline \multirow{4}{*}{$\begin{array}{l}\text { Pools of CSF from } \\
\text { four rabbits }\end{array}$} & 24 hrs & Tp positive & Negative passage & \\
\hline & 9 days & Tp positive & Positive passage & 26 \\
\hline & 12 days & Tp positive & Positive passage & 21 \\
\hline & 65 days & Tp positive & Negative passage & \\
\hline
\end{tabular}


The result of the bacteriological examination was positive in all four cases ; however, after intratesticular injection of these four pools into four fresh rabbits, we obtained a positive result only twice, with the mixtures of CSF from four rabbits that had been infected with syphilis 12 and 9 days previously, after incubation periods of 21 and 26 days respectively; the other two remained negative (Fig. 2).

(2) EXAMINATION OF AQUEOUS HUMOUR (Table II) In the light of the communications from Smith, Singer, Moore, and Yobs (1965), Smith, Singer, Reynolds, Moore, Yobs, and Clark (1965), Smith and Taylor (1965), Smith and Israel (1967a, b, 1968), Goldman and Girard (1967, 1968), Rice, Jones, and Wilkinson (1968), and Rice, Dunlop, Jones, Hare, King, Rodin, Mushin, and Wilkinson (1970), we examined 26 smears of aqueous humour from infected rabbits, between $3 \mathrm{hrs}$ and 480 days after the initial inoculation.

Upon examining these slides, stained by the silver method, we were able to detect $T$. pallidum in each of the specimens, collected from $24 \mathrm{hrs}$ to 480 days after the initial inoculation (Fig. 3, overleaf), but not those collected between 3 and $6 \mathrm{hrs}$ after inoculation.

It should, however, be noted that the aqueous humour collected 480 days after the inoculation was from a rabbit with interstitial keratitis whose aqueous humour contained a slightly higher count of $T$. pallidum than in the other cases, since we were able to find treponemes by darkfield examination.
We then proceeded, as in the case of the CSF, to make intratesticular injections of aqueous humour but, since only a very small quantity of liquid (approximately $0.2 \mathrm{ml}$.) can be obtained by puncture of the anterior chamber of the eye, we decided it was preferable to use the pool method, grouping together animals that had been infected for similar periods of time.

Three pools were thus constituted, on the 9th, 44th, and 52nd days. However, it was only in the case of one pool from four rabbits that had been infected for 44 days, without any ocular manifestations but in which microscopic examination clearly demonstrated the presence of $T$. pallidum, that intratesticular injection into a fresh recipient produced orchitis with numerous treponemes after an incubation period of 40 days (Fig. 4, overleaf). The other two transfers remained negative.

(3) EXAMINATION OF CSF AND AQUEOUS HUMOUR IN MAN Concurrently with these investigations, we continued our research on 35 specimens of CSF and aqueous humour from 25 cases of late symptomatic syphilis, eight of latent syphilis, and two of secondary syphilis; eighteen patients had been treated and seventeen were untreated.

The findings were positive in 25 of the CSF smears and in twelve of the aqueous humour smears. Treponemes were found in roughly the same proportion of treated and untreated cases, but some patients had been treated long ago with arsenicals, bismuth, and mercury.

TABLE I I Results of bacteriological tests on smears of aqueous humour from infected rabbits (untreated) and of intratesticular inoculations into fresh rabbits

\begin{tabular}{|c|c|c|c|c|}
\hline No. of rabbits & $\begin{array}{l}\text { Duration of infection before } \\
\text { collection of material }\end{array}$ & $\begin{array}{l}\text { Results of bacteriological } \\
\text { tests }\end{array}$ & $\begin{array}{l}\text { Results of injection of } \\
\text { aqueous humour into testes of } \\
\text { fresh rabbits }\end{array}$ & $\begin{array}{l}\text { Duration of } \\
\text { incubation } \\
\text { period (days) }\end{array}$ \\
\hline 2 & 3 and $6 \mathrm{hrs}$ & Tp 2 negative & & \\
\hline 2 & 24 and $48 \mathrm{hrs}$ & Tp 2 positive & & \\
\hline $\begin{array}{l}\text { Pool of aqueous } \\
\text { humour from four } \\
\text { rabbits }\end{array}$ & 9 days & Tp positive & Negative passage & \\
\hline 2 & 25 and 40 days & Tp 2 positive & & \\
\hline $\begin{array}{l}\text { Pool of aqueous } \\
\text { humour from four } \\
\text { rabbits }\end{array}$ & 44 days & Tp positive & Positive passage & 40 \\
\hline $\begin{array}{l}\text { Pool of aqueous } \\
\text { humour from four } \\
\text { rabbits }\end{array}$ & 52 days & Tp positive & Negative passage & \\
\hline 3 & 78,81 , and 90 days & Tp 3 positive & & \\
\hline 4 & $130,224,230$, and 283 days & Tp 4 positive & & \\
\hline 1 & 480 days & $\begin{array}{l}\text { Tp positive } \\
\text { Interstitial keratitis }\end{array}$ & & \\
\hline
\end{tabular}




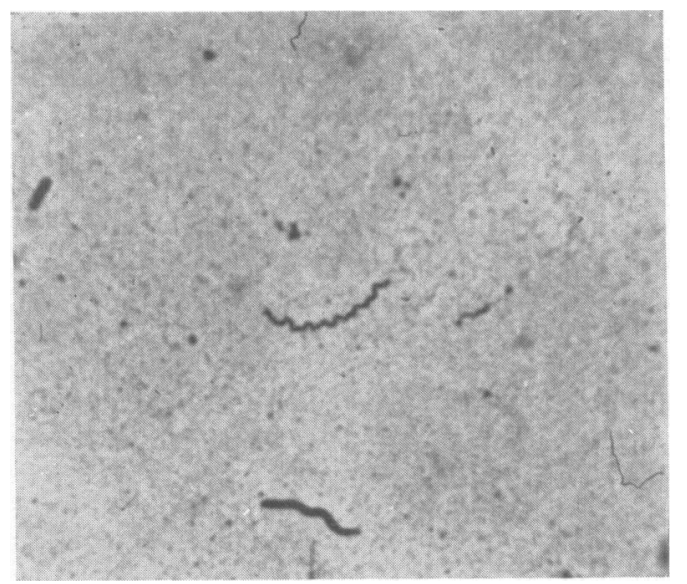

FIG. 3 Smear of aqueous humour from a rabbit inoculated 8 days earlier

However, we performed only one inoculation into an animal, and that with a negative result. We had previously tried nine times to produce infection by injecting CSF collected from syphilitics with visceral or latent disease into rabbit testes, but in vain, yet over 60 years ago Volk (1913) and Marinesco and Minea (1913), and also Frühwald and Zaloziecki (1916), had been more successful than we were.

\section{Discussion}

Although some transfers did give positive responses, we are entitled to wonder, in view of the number of negative passages, whether all the spirochaetes detected in the smears were really $T$. pallidum.

To answer this question, we began by examining with equally close attention five CSF and four aqueous humour specimens obtained from healthy animals and also CSF specimens from six human subjects who had never had syphilis. None of these examinations yielded any spiral organisms.

We then asked ourselves whether other spirochaetes might be involved.

In the case of the rabbit, one might have suspected Treponema paralues cuniculi, but none of our animals had displayed any evidence of that infection. Moreover, Pettit (1928) clearly showed that $T$. cuniculi does not become disseminated in the internal organs of the animal but always remains localized in the superficial structures.

As for the saprophytic spirochaetes which are generally to be found in man's natural orifices, they do not penetrate the tissues to any depth or become disseminated. If they did so, it should be possible to observe this in healthy individuals, which our investigations have shown not to be the case.

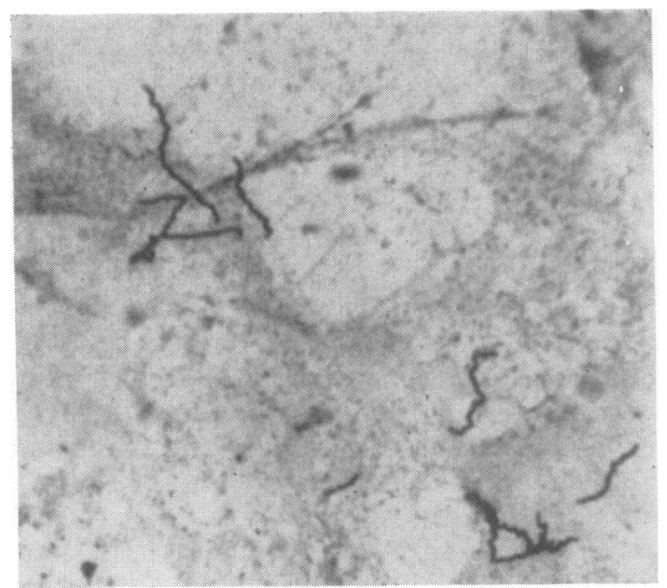

FIG. 4 Smear of material from acute orchitis after intratesticular inoculation of a 'pool' containing mixed aqueous humour from rabbits infected $\mathbf{4 4}$ days earlier

How then are we to explain the many negative passages with inocula in which microscopic examination revealed the presence of $T$. pallidum?

To tackle this question, we felt it would be interesting to make a comparative study of the phenomena observed in the course of similar investigations of lymphatic tissue.

We know that $T$. pallidum spreads throughout the entire organism with extreme rapidity. Raiziss and Severac (1937) were able to demonstrate that the blood stream of rabbits was infected within 5 minutes after intratesticular inoculation. Bessemans and de Potter (1933, 1934) and Kolle and Evers (1926) showed that the lymphatic tissue was infective in a fresh animal 30 minutes after inoculation, and Tani, Ogiuti, Hutaki, and Oya (1935) that it was infective after 5 minutes.

It is therefore not surprising that $T$. pallidum can be detected very early in various organs.

In practice, however, while it is undeniable that these micro-organisms invade the lymphatic tissue very early, they are usually very difficult to detect during the first 10 days after the initial inoculation, not only because they are few in number but also because the smears are loaded with a variety of substances and with cell debris (Table III, opposite).

Thus, out of twelve lymph-node specimens collected at intervals ranging from $1 \frac{1}{2} \mathrm{hrs}$ to 9 days after the initial infection, only two (collected after $48 \mathrm{hrs}$ and 3 days respectively) yielded smears in which we were able to find $T$. pallidum, whereas we obtained two positive passages with the specimens collected after $18 \mathrm{hrs}$ and on the 3rd day, even though the 
TABLE II R Results of bacteriological tests on lymph-node smears from infected rabbits (untreated) and of intrascrotal passages in fresh rabbits

\begin{tabular}{|c|c|c|c|c|}
\hline No. of rabbits & $\begin{array}{l}\text { Duration of infection before } \\
\text { collection of material }\end{array}$ & $\begin{array}{l}\text { Results of bacteriological } \\
\text { tests }\end{array}$ & $\begin{array}{l}\text { Results of intrascrotal } \\
\text { passages in fresh rabbits }\end{array}$ & $\begin{array}{l}\text { Duration of } \\
\text { incubation } \\
\text { period (days) }\end{array}$ \\
\hline 5 & $1 \frac{1}{2}, 18,20,48$, and $48 \mathrm{hrs}$ & $\begin{array}{l}\text { Tp } 1 \text { positive }(48 \mathrm{hrs}) \\
3 \text { negative }\end{array}$ & $\begin{array}{l}1 \text { positive passage }(18 \mathrm{hrs}) \\
2 \text { negative passages }\end{array}$ & 49 \\
\hline 7 & $3,3,4,4,5,5$, and 9 days & $\begin{array}{l}\text { Tp } 1 \text { positive ( } 3 \text { days) } \\
6 \text { negative }\end{array}$ & $\begin{array}{l}1 \text { positive passage ( } 3 \text { days) } \\
1 \text { negative passage }\end{array}$ & 69 \\
\hline 9 & $\begin{array}{l}10,11,12,41,45,45,52,61, \\
\text { and } 94 \text { days }\end{array}$ & Tp 9 positive & $\begin{array}{l}3 \text { positive passages } \\
(11,61 \text {, and } 94 \text { days })\end{array}$ & average 35 \\
\hline 5 & $\begin{array}{l}140,179,222,222 \text {, and } 307 \\
\text { days }\end{array}$ & $\begin{array}{r}\text { Tp } 4 \text { positive } \\
1 \text { negative }\end{array}$ & 4 positive passages & average 46 \\
\hline 46 & average 2 years & $\begin{array}{r}\text { Tp } 40 \text { positive } \\
6 \text { negative }\end{array}$ & $\begin{array}{l}34 \text { positive passages } \\
12 \text { negative passages }\end{array}$ & average 50 \\
\hline 7 & 3 years & $\begin{array}{l}\text { Tp } 5 \text { positive } \\
2 \text { doubtful }\end{array}$ & $\begin{array}{l}1 \text { positive passage } \\
6 \text { negative passages }\end{array}$ & 41 \\
\hline
\end{tabular}

examination of the corresponding smears had given negative results.

Furthermore, the length of the incubation period (49 and 69 days respectively) noted at this phase can only be due to the low $T$. pallidum content of the lymph-node material transferred, whereas at this same stage (which is that of the onset of orchitis and hence corresponds to the exponential growth phase of the treponemes), the testicular tissue is, in contrast, highly infective.

From the 10th day up to about 1 year after the inoculation, all the microscopic examinations (except in one case on the 140th day) and also the passages into recipients proved to be positive with a shorter incubation period.

Although 2 years after the inoculation, $T$. pallidum can still be found in 40 out of 46 of the smears, only two thirds of the results obtained are positive, with an incubation period of 50 days; and after 3 years, only one out of seven of the passages gives a response, though $T$. pallidum is still present in five out of seven of the lymph-node smears (Collart, Poggi, Dunoyer, and Dunoyer, 1967).

\section{Conclusions}

Our observations clearly show that, while $T$. pallidum spreads extremely rapidly after entering the body, only very small numbers of micro-organisms invade certain tissues, particularly the CSF and the aqueous humour, where they multiply far more slowly than during the period of exponential growth in the testes. If this were not so, we should be able to detect a substantial increase in the number of $T$. pallidum in the various structures.
No doubt the treponemes thus detected had retained their vitality, as proved by the few positive passages in fresh animals which we obtained; if this were not so, they would have been lysed or eliminated.

There is, therefore, every reason to suppose that the spirochaetes do not multiply every 30 to $33 \mathrm{hrs}$ as during the period of exponential growth which precedes the onset of acute orchitis, but instead vegetate in situ, dividing only at very long intervals.

It is probably because of the small number of micro-organisms present at these sites and their quiescent state that transfers to fresh animals so seldom give positive results. It would seem to be because of this state of latency that such treponemes generally prove 'insensitive' to the effect of penicillin, an antibiotic which acts upon these micro-organisms only during the period of multiplication, as we have been able to show in a previous study (Collart, Pechère, Franceschini, and Dunoyer, 1972).

\section{Summary}

A new method, derived from that proposed by Chandler and Clark in 1970, for detecting T. pallidum in the cerebrospinal fluid or aqueous humour, is described.

After filtration through a Millipore membrane, the upper side of the filter is laid against a slide to produce smears which are then silver-stained by Dunoyer's method (adapted from Dieterle's technique).

It was shown that $T$. pallidum spreads very rapidly through the organism after the initial inoculation. Positive results obtained by passaging 'pools' of CSF or aqueous humour from rabbits proved that the spirochaetes observed were in fact $T$. pallidum and that they had retained their vitality. 
Since, however, the quantity of $T$. pallidum thus detected always remains small, even long after the onset of the infection, there is every reason to think that the micro-organisms vegetate in a latent state without multiplying (or multiplying only very slowly); this could explain not only the difficulty of obtaining positive passages with this material containing small quantities of quiescent treponemes, but also the lack of sensitivity of these treponemes to pencillin, which acts only during periods of division.

\section{References}

Bessemans, A., and De Potter, F. (1933) Bull. Acad. Méd., 109,908

-1 (1934) Ibid., 112, 132

Chandler, F. W., Jr. (1969) Brit. F. vener. Dis., 45, 305 and Clark, J. W., Jr. (1970) WHO/VDT/70.226

Chesney, A. M., and KeMP, J. E. (1924) f. exp. Med., 39, 553

Collart, P., Borel, L.-J., and Durel, P. (1962) Ann. Inst. Pasteur, 102, 596

-, Pechère, J. C., Franceschini, P., and Dunoyer, P. (1972) Brit. F. vener. Dis., 48, 29

- Poggi, G., Dunoyer, M., and Dunoyer, F. (1967) Path. et Biol., 15, 470

FrüHWAld, R., and Zaloziecki, A. (1916) Berl. klin. Wschr., 53, 9

Goldman, J. N., and GIRARD, K. F. (1967) Arch. Ophthal. (Chicago), 78, 47

- (1968) Ibid., 79, 716

Kolle, W., and Evers, E. (1926) Dtsch. med. Wschr., 52, 1075

Marinesco, G., and Minea, J. (1913) Bull. Acad. Méd., 69, 235

NEDDEN, M. ZUR (1906) Ber. dtsch. ophthal. Ges. (Heidelberg), 33, 215

Nichols, H. J., and Hough, W. H. (1913) f. Amer. med. Ass., 60, 108

Pettit, A. (1928) 'Contribution à l'étude des spirochétidés', vol. 1, p. 93. Chez l'auteur, Vanves

Raiziss, G. W., and Severac, M. (1937) Arch. Derm.Syph. (Chicago), 35, 1101

Rice, N. S. C., DunLoP, E. M. C., Jones, B. R., HARE, M. J., KING, A. J., Rodin, P., Mushin, A., and Wilkinson, A. E. (1970) Brit. F. vener. Dis., 46, 1 , JoNes, B. R., and WILKINSON, A. E. (1968) Trans. ophthal. Soc. U.K., 88, 257
Schaudinn, F. R., and Hofrmann, P. E. (1905) Arb. $k$. GesundhAmte, 22, 527

Sézary, A., and Paillard, R. (1910) C.R. Soc. Biol., 68, 295

Smith, J. Lawton, and Israel, C. W. (1967a) Arch. Ophthal. (Chicago), 77, 474

—_ (1967b) F. Amer. med. Ass., 199, 980 72, 63 (1968) Trans. Amer. Acad. Ophthal. Otolaryng.,

-, Singer, J. A., Moore, M. B., and Yobs, A. R. (1965) Amer. F. Ophthal., 59, 753

,,-- ReYNolds, D. H., MOORE, M. B., YoBs, A. R., and ClARK, J. W. (1965) Brit. F. vener. Dis., 41, 15

- and TAYLOR, W. H. (1965) Amer. F. Ophthal., 60, 653

STEPHENSON, S. (1907) Ophthalmoscope, 5, 303

Tani, T., Ogiuti, K., Hutaki, H., and Oya, I. (1935) Zbl. Bakt., Abt. 1 (Orig.), 134, 54

VoLk, R. (1913) Wien. klin. Wschr., 26, 1824

WiLE, U. J. (1917) Amer. F. Syph., 1, 84

Méthode modifiée de filtration du liquide céphalorachidien et de l'humeur aqueuse pour la détection des tréponèmes. Preuve de la persistance de leur vitalité chez le lapin

\section{SOMMAIRE}

Les auteurs décrivent une nouvelle méthode dérivée de celle préconisée par Chandler et Clark (1970) pour la recherche des tréponèmes pâles dans le LCR ou bien dans l'humeur aqueuse.

Après avoir filtré sur une membrane millipore, la face supérieure de celle-ci est appliquée sur une lame pour effectuer des frottis qui sont alors colorés par l'argent selon la méthode de Dunoyer (dérivée de celle de Dieterlé).

Ils ont pu montrer ainsi que les $\mathrm{Tp}$ se disséminent très rapidement dans l'organisme après l'inoculation virulente de l'animal. Des passages positifs effectués avec des "pools" de LCR ou d'humeur aqueuse apportent la preuve que ces spirochètes sont bien des $T p$ et qu'ils ont conservé leur vitalité.

Mais la quantité de $\mathrm{Tp}$ ainsi décelée restant toujours faible, même longtemps après le début de l'infection, tout permet de penser que ces germes y végètentà l'état de latence sans se multiplier (ou seulement fort lentement), ce qui pourrait expliquer non seulement la difficulté d'obtenir des passages positifs avec ce matériel pauci-infecté de spirochètes quiescents, mais aussi l'absence de sensibilité de ces $T p$ à la pénicilline, celle-ci n'agissant qu'en période de division. 